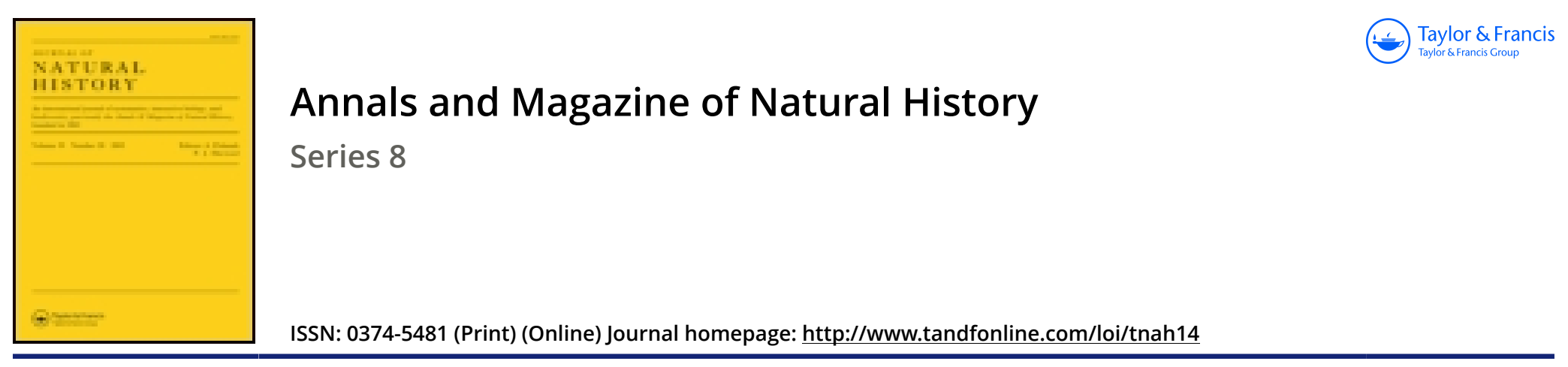

\title{
XXV.-fishes from Yunnan, collected by Mr. John Graham, with description of a new species of Barilius
}

\section{Tate Regan M.A.}

To cite this article: C. Tate Regan M.A. (1914) XXV.-fishes from Yunnan, collected by Mr. John Graham, with description of a new species of Barilius, Annals and Magazine of Natural History, 13:74, 260-261, DOI: 10.1080/00222931408693474

To link to this article: http://dx.doi.org/10.1080/00222931408693474

Published online: 15 Sep 2009.

Submit your article to this journal $\square$

Q View related articles ๘

Citing articles: 1 View citing articles $\square$ 
between it and the still earlier Aphareus inermis of Paulson tend to lose their importance. One specimen among Borradaile's material has the rostral crest shaped almost exactly as in Paulson's figure, owing, apparently, to the breaking of the anterior tooth; the greater stoutness of the third cheliped as figured by Paulson is not likely to be a valid specific character in view of the great difference between the sexes in this respect ; and the number of articulations in the penultimate segment of the third maxilliped is sometimes difficult to determine unless the limb be removed from the body. The decision on this point, however, may be left to Dr. Balss, who, I understand, has under examination specimens belonging to this genus from the Red Sea.

There remains for consideration the systematic place to be assigned to the genus, and on this point I find myself unable to agree with Borradaile's suggestion that its affinities are with the Sicyoninæ. The characters enumerated in my former paper appear to show conclusively that it belongs to the Sergestidx, and in addition it may be pointed out that the branched form of the adult male petasma is very suggestive of that found in Sergestes [cf. Kemp, Fisheries, Ireland, Sci. Invest. 1908, i. (1910) pl. iii. figs. 11 \& 14] and quite unlike that of Sicyonia. The modification of the inner flagellum of the antennule in the adult male, as described above, is probably to be compared with the prehensile apparatus of Sergestes, although the flagellum is not bifurcated as in that genus.

XXV.-Fishes from Yunnan, collected by Mr. John Graham, with Description of a new Species of Barilius. By C, TATE REgaN, M.A.

(Published by permission of the Trustees of the British Museum,)

During the last ten years Mr. John Graham has from time to time sent several small collections of fishes from Yunnan to the British Museum; one just received is likely to be the last, as Mr. Graham in leaving Yunnan; it includes examples of a new Burilius.

Barilius alburnops, sp. $\mathrm{n}$.

Depth of body $4 \frac{1}{2}$ to 5 in the length, length of head $3 \frac{1}{2}$ to 4 . Snout nearly equal to diameter of eye, which is $3 \frac{2}{3}$ to 4 in 
the length of head and equal to or a little less than interorbital width. Mouth oblique; maxillary not extending to below eye; no barbels. Scales 76 to 84,12 or 13 from dorsal fin to lateral line, 3 from lateral line to base of pelvics. Dorsal 10, with 7 branched rays; origin just behind base of pelvics, nearer to caudal fin than to end of snout. Anal 1618, with 13 to 15 branched rays. Pectoral extending $\frac{3}{5}$ to $\frac{3}{4}$ of distance from its base to pelvics. Caudal forked. Caudal peduncle twice as long as deep. Silvery; back olivaceous; fins immaculate.

Yunnan Fu.

Several specimens, 150 to $200 \mathrm{~mm}$. in total length.

It may, perhaps, be of interest to give a complete list of the fishes sent by Mr. Graham from Yunnan; all the new species have been described in the 'Annals,' and the dates appended will lacilitate reference to the original descriptions :-

Cyprinus carpio, Linn.

Clicristius, Regan, 1906.

Carassius auratus, Linn.

Barbus grahami, Regan, 1904.

- yunnanensis, Regan, 1904.

Discognathus yunnanensis, Regan, 1907.

Oreinus grahami, Regan, 1904.

Schirothorax taliensis, Regan, 1907.

Achilognathus barbatulus, Giinth.

Acanthorhodeus elongatus, Regan, 190.\%.

Barilius polylepis, Regan, 1904. andersoni, Regan, 1904. grahami, Regan, 1908. alburnops, Regan, 1914.

Misgurnus anyuillicaudatus, Cantor.

Nemachilus pleurotania, Regan, 1904.

- nigromaculatus, Regan, 1904.

- oxygnathus, Regan, 1908. grahami, Regan, 1906. mongolicus, Bleek.

Silurus mento, Regan, 1904.

- grahami, Regan, 1907.

Pseudobrarus medianalis, Regan, 1904.

Liobagrus nigricauda, Regan, 1904.

Ophiocephalus argus, Cantor.

Monopterus javanensis, Lacep.

XXVI.-Two new Cyprinid Fishes from Waziristun, collected by Major G. E. Bruce. By C. Tate Regan, M.A.

(Published by permission of the Trustees of the British Museum.)

MAJor G. E. BruCE has presented to the British Museum a small collection of fishes made in the Wana Toi, a tributary of the Gomal River in Southern Waziristan $\left(32^{\circ} 20^{\prime} \mathrm{N}\right.$., $69^{\circ} 30^{\prime}$ E., altitude 4500 feet). Six species are represented : four of these, Callichrous pabda, Ham. Buch., Barilius Ann. \& Mag. N. Hist. Ser. 8. Vol. xiii. 